\title{
ThE EFFECTIVENESS OF PUbLiC FACILITIES IN LOW COST HOUSING FLATS FROM RESIDENTIAL SATISFACTION TOWARDS SUSTAINABLE LIVING
}

\author{
Alice Sabrina Ismail ${ }^{\star}$ \\ Department of Architecture, Faculty of Built Environment and Surveying \\ Universiti Teknologi Malaysia \\ Malaysia \\ b-alice@utm.my
}

\section{NorShahida Azili}

Department of Architecture, Faculty of Built Environment and Surveying Universiti Teknologi Malaysia

Malaysia

norshahida.a@utm.my

\section{Fadhlina Ahmad@ Taufik}

Department of Architecture, Faculty of Built Environment and Surveying Universiti Teknologi Malaysia

Malaysia

fadhlina@utm.my

*Corrosponding author's Email: $\underline{\text { b-alice@ utm.my }}$

Peer-review under responsibility of 5th ${ }^{d}$ Asia International Conference 2019 Scientific Committee http://connectingasia.org/scientific-committee/ (C) 2019 Published by Readers Insight Publisher, lat 306 Savoy Residencia, Block 3 F11/1,44000 Islamabad. Pakistan, editor@readersinsight.net This is an open access article under the CC BY-NC-ND license (http://creativecommons.org/licenses/by-nc-nd/4.0/). 


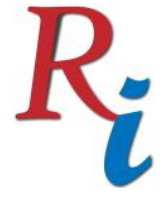

\section{Asia Proceedings of Social Sciences}

(APSS)

www.readersinsight.net/APSS

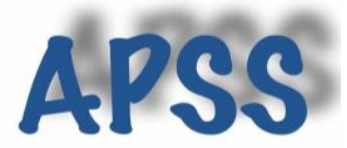

\section{A b s tract}

Public facilities which defined as institutional responses to human needs plays an essential role in providing support services to create viable living for unified communities. Since the provided public facilities depends on the size of the area that they serve, the aspects of preparing and managing public facilities are vital to ensure residential comfort. So far there has been no studies reviewing on this matter except on aspects like the accessibility, provisioning and service requirements for public facilities namely in low cost housing development. The objective of this study is to obtain residents satisfaction in terms of public facilities maintenance effectiveness to establish appropriate design attributes using mix methods technique. Findings are gathered using questionnaire method as well as conducting direct observation on the two selected case study in its natural setting. The outcome indicates that residents are not satisfied with public facilities features located within the low-cost social housing environment. Therefore, proper preparation and managing of public facilities are needed for the development of positive psychological behavior among residents to ensure their well-being and living comfort. This study is important to enhance the quality of public facilities for residents in low cost housing towards better satisfaction for fostering sustainable living in the future.

\section{Rese a r ch H igh I ight s}

This study highlights on the lower -order type of public facilties which are utilised by a single or a limited number of residential communities(Alam \& Ahmad, 2013). Even though, there are three types of public facilities commonly found in residential urban settlements which are health and safety, education and the recreational, the focus will be on recreational type as it much involve provision of activity spaces for all groups of people to communicate, integrate, play as well as to socialize actively. The most prevalent recreational public faciltites in low cost housing are community hall, open yard, futsal court, and green field. In this sense, recreational public facilties are more dominant as it allows all communal members regardless of age, race and background to utilize this amenities for organizing and performing activities together(Hashim, Samikon, Ismail, \& Ismail, 2015). This is because, by frequent usage of public facilities, communities will have the tendency to interact, recognize as well as socialize 


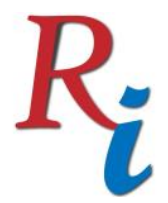

\section{Asia Proceedings of Social Sciences}

(APSS)

www.readersinsight.net/APSS

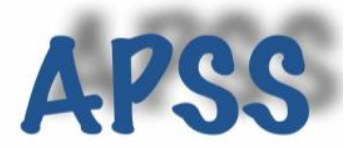

with each other in healthy way. This stimulates the feeling of belongingness and sense of responsibility among them(Verhage \& Needham, 2017). As a result, will inevitably create sense of surveillance within their settlement to encourage much safer, sustainable and harmonious living territory.

\section{Research Objectives}

This study aims to achieve three main objectives. First, is to identify the types of communal facilities provided in urban low-cost housing. Second, to outline the existing communal facilities for residents in low-cost housing and third, to assess the effectiveness of these communal facilities for residents satisfaction towards the development of psychological wellbeing and the promotion of positive values among them. This study is significant as it will provide an overview on the effectiveness of public facilities design in low cost housing on propagating positive moral values among residents. These positive moral values are vital in nurturing sustainable social life among dwellers(Ibem, 2013). These values are also important to cultivate the formation of caring society and promote constructive personality among individuals with optimistic world view. In relation to this, the provision of communal facilities should be attractive to the community's culture in the residential area. Due to this, findings from the selected case studies suggests guidelines as method for improving and enhancing the presence of communal facilities in low-cost housing for future reference. This is important to create a more comfortable and harmonious living environment in the future.

\section{Methodology}

This study makes use of case studies as research strategy under the framework of mixed methods to derive detailed findings so that comprehensive conclusion can be obtained. Two case studies which are Perumahan Awam Seri Perlis 2 in Kuala Lumpur and Perumahan Awam Lima Kedai at Gelang Patah are chosen for this research. Justification selection for these case studies are based upon two main criteria. The first criterion is that both flats represents mediumhigh low-cost flats typology and subjected within the multi-level low cost housing category as outlined by the Housing Ministry and Local Government(Malek \& Husin, 2012). The second criterion is based on the location and placement of these low-cost flats, in which both are located within the urban context. Location is an important aspect because it indirectly 


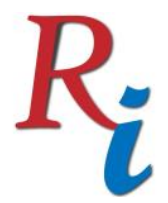

\section{Asia Proceedings of Social Sciences}

(APSS)

www.readersinsight.net/APSS

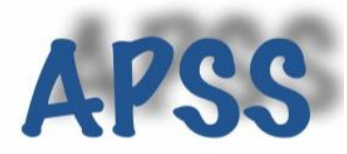

influences the surrounding development of the flats(Husin, Malek, \& Gapor, 2012). According to scholars, the density of the population is more critical in city areas as compared to suburbs and is always laden with more serious social problems that involves various ethnic and racial backgrounds, age groups and gender(Salleh, 2008). For data gathering methods, this study uses literature review and direct observation for qualitative approaches. This is vital to generate new ideas and provide an opportunity for researchers to present their views and validate the proof of findings on the present condition of public facilities. Close-ended questionnaires on 300 respondents from different age group, race and cultural background on the other hand, is used as quantitative method to gather data on the role and effectiveness of public facilities found in the two low cost housing development. The selective justification of these respondents are based on the population capacity of the low-cost flats as well as referring to the Limit Theorem efficacy that covers the population size to an infinite capacity(Ibem \& Alagbe, 2015). Questionnaires are important to understand the level of satisfaction among residents towards fostering sustainable living. The findings then are analyzed in two phases. First, data from literature review and direct observation uses hermeneutic via coding as analysis technique. This method of analysis is vital as it introduces new ways of looking at public facilities as a system of 'sign' based on indicators involving location, placement, hierarchy, accessibility, circulation configuration, spatial arrangement, functionality, thermal comfort and acoustic level. Second, data from questionnaires are analyzed using SPSS method. All collected data then is used to propose for the best possible design guideline for public facilities in low cost housing to achieve the objective of the study.

\section{Results}

Results indicate that many respondents tend to agree that the provided public facilities do not fully meet the basic needs of the population within the vicinity of low cost housing area. In addition, the public facilities provided are not able to shape and influence the development of good psychological traits among users. This can be identified from the aspects of public facilities form making such as the physical and quality facets which involve functionality and utility. This is because public facilities portrayed in both case studies showed no consideration in evoking sense of belonging or attachment among users. As a result, causing residents to ignore and neglect the existence of these public facilities. Based on the findings, the public 


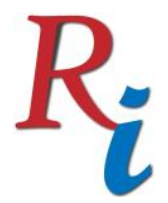

\section{Asia Proceedings of Social Sciences}

(APSS)

www.readersinsight.net/APSS

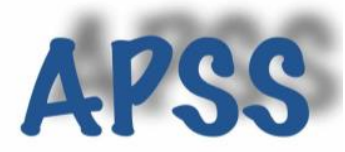

facilities were not designed with an appearance that can create sense of appreciation among users to care for and to respect these public facilities. In addition, the public facilities provided have not succeeded in creating an environment with "third place" characteristics that emphasizes on conducive feeling and accommodating social environment fulfilling users' needs and emotions.Hence, the residents felt that their needs are not met and justified. The existence of this "third place" concept is important in shaping and uniting a community as it can triggers sense of place within individuals.

\section{Findings}

Public facilities namely in housing development should be well designed according to residents' satisfactions in terms of placement with better accessibility and usability. In this sense, the location of public facilities should be easy to visit in which the distance of the public facilities provided ought to meet the requirements of pedestrians at a comfortable pace and distance. Placement of public facilities should also emphasize on the security risk aspects in site to ensure the safety of users. This in return will creates sense of belonging and connection between the residents with these public facilities. Indirectly this will induce a sense of attachment among residents with these facilities which contributes to viable living. From this, in the planning of public facilities there are two main aspects that contribute to the level of residential well-being. First, are the physical aspects that includes the form making in which needs to be attractive and practical. Second is the functional and serviceable aspect that includes space making of the public facilities. These aspects are important as they can lead to a conducive 'third place' environment. Governments including developers and relevant authorities should consider the importance of public facilities in housing development namely the low cost residential, so that sustainable living environment can be nurtured in the future.

\section{References}

Alam, M. J., \& Ahmad, M. M. (2013). Public Facilities in Public and Private Housing Projects in Dhaka, Bangladesh. Urban Policy and Research, 31(2), 190-207.

Hashim, A. E., Samikon, S. A., Ismail, F., \& Ismail, Z. (2015). Managing facilities on Malaysian low-cost public residential for sustainable adaptation. Procedia-Social and Behavioral Sciences, 168, 52-60. 


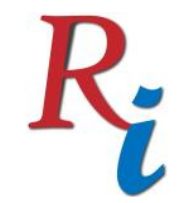

\section{(APSS) \\ www.readersinsight.net/APSS}

Asia Proceedings of Social Sciences

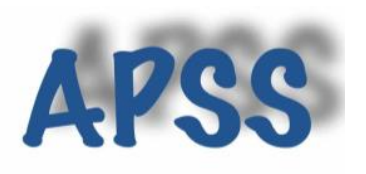

Husin, A., Malek, N. M., \& Gapor, S. A. (2012). Cultural and Religious Tolerance and Acceptance in Urban Housing: A Study of Multi-Ethnic Malaysia. Asian Social Science, 8(2), 112-118.

Ibem, E. O. (2013). Accessibility of services and facilities for residents in public housing in urban areas of Ogun State, Nigeria. Paper presented at the Urban Forum.

Ibem, E. O., \& Alagbe, O. A. (2015). Investigating dimensions of housing adequacy evaluation by residents in public housing: Factor analysis approach. Facilities, 33(7/8), 465-484.

Malek, N. M., \& Husin, A. (2012). Pemilikan rumah dalam kalangan masyarakat bandar berpendapatan sederhana dan rendah di Malaysia. Sosiohumanika, 5(2).

Salleh, A. G. (2008). Neighbourhood factors in private low-cost housing in Malaysia. Habitat International, 32(4), 485-493.

Verhage, R. f., \& Needham, B. (2017). Financing public facilities in housing projects: a method for understanding negotiating processes. In Infrastructure Provision and the Negotiating Process (pp. 31-50): Routledge.

\section{Author's Biography}

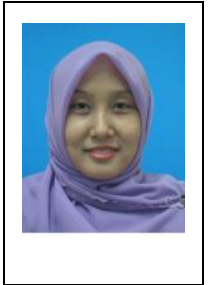

Alice Sabrina Ismail is an Associate Profesor at the Department of Architecture in Faculty of Built Environment and Survey Universiti Teknologi Malaysia. After obtaining her PhD in Architecture History and Theory from Queensland University Technology in 2008, she had been actively involved in many architectural research works, publications and community works on social housing and sustainable development as well as architecture design education with various private bodies and government agencies. 